\title{
PENGEMBANGAN VIDEO PEMBELAJARAN MATA KULIAH PENGUJIAN BAHAN PANGAN MATERI SIFAT TELUR
}

\author{
Andian Ari Anggraeni ${ }^{1}$, Mutiara Nugraheni ${ }^{2}$, Wika Rinawati ${ }^{3}$ \\ 1,2,3Program Studi Pendidikan Teknik Boga Universitas Negeri Yogyakarta \\ Email: andian_ari@uny.ac.id
}

\begin{abstract}
ABSTRAK
Tujuan penelitian ini: mengembangkan dan menilai kelayakan video pembelajaran mata kuliah Pengujian Bahan Pangan untuk materi telur oleh ahli materi, ahli media dan calon pengguna. Penelitian ini merupakan penelitian pengembangan. Pengembangan video pembelajaran dilakukan dengan pendekatan 4D (Define, Design, Develop dan Dissemination). Video pembelajaran ini menjelaskan sifat fisik dan emulsi telur. Metode pengumpulan data menggunakan angket penilaian kelayakan media. Uji coba terbatas video pembelajaran dilakukan pada 30 orang mahasiswa Pendidikan Teknik Boga, Universitas Negeri Yogyakarta. Hasil penelitian menunjukkan bahwa: 1) video pembelajaran mata kuliah Pengujian Bahan Pangan untuk materi sifat fisik dan emulsi telur telah dikembangkan dengan format mp4, durasi 11 menit, dan terdiri dari 5 bagian yaitu pembukaan, persiapan alat dan bahan, eksperimen, evaluasi hasil dan penutupan. Video diunggah dalam YouTube channel Pendidikan Teknik Boga Universitas Negeri Yogyakarta dengan URL https://youtu.be/l0b_F_2pAQU. 2) nilai kelayakan video pembelajaran berdasar ahli materi 96\% kategori sangat layak, ahli media 88\% sangat layak dan calon pengguna 83\% sangat layak, sehingga video pembelajaran ini sangat layak digunakan sebagai media pembelajaran.
\end{abstract}

Kata Kunci: pengujian bahan pangan, video pembelajaran,

\section{PENDAHULUAN}

Mata kuliah Pengujian Bahan Pangan merupakan mata kuliah wajib di program studi Pendidikan Teknik Boga, yang diberikan pada semester 4. Mata kuliah ini merupakan mata kuliah 3 SKS praktik, yang membahas tentang konsep teoritis, faktual, dan prosedural tentang pengujian bahan pangan yang memberikan pengetahuan bahan pangan baik hewani maupun nabati serta menguji suatu bahan pangan dalam kaitannya dengan pengaruh pengolahan terhadap gizi suatu pangan, prinsip analisis gizi dan acuan label gizi.

Bahan ajar yang selama ini digunakan meliputi hand-out, slide presentasi dan labsheet. Berdasarkan hasil observasi terhadap pelaksanaan kuliah selama ini, mahasiswa sering tidak mempersiapkan materi dengan baik. Hal ini disebabkan karena mahasiswa tidak membaca labsheet mengenai bahan, alat dan langkah kerja pelaksanaan praktik. Persiapan yang tidak maksimal ini berakibat pada penurunan sikap kemandirian mahasiswa saat praktik.

Praktik kuliah Pengujian Bahan Pangan dilakukan secara kelompok. Setiap kelompok mendapat tugas praktik yang berbeda dari kelompok lainnya. Setelah praktik selesai, setiap kelompok diminta untuk mempresentasikan hasil praktik kelompok masing-masing. Melalui kegiatan presentasi ini, diharapkan setiap mahasiswa memahami praktik yang dilakukan oleh kelompok lain. Oleh karena itu, proses diskusi antara anggota kelompok dan presentasi kelompok merupakan proses yang sangat penting dalam pencapaian kompetensi semua mahasiswa. Berdasar hasil observasi dosen, mahasiswa kadang tidak memahami penjelasan kelompok lain. Selain itu, berdasar feedback dari mahasiswa, ada beberapa materi pengujiandalam mata kuliah ini yang dirasa masih susah untuk dimengerti.

Proses belajar mengajar di kelas pada umumnya masih menggunakan model pembelajaran konvensional atau tradisional, 
yaitu dengan dengan metode ceramah. Metode ini disebut dengan teacher centered learning (TCL). Pada metode TCL, pembelajaran berlangsung satu arah. Dosen bertugas menyampaikan materi, sehingga dosen menjadi pusat dalam pencapaian hasil pembelajaran dan menjadi satu-satunya sumber ilmu. Sedangkan mahasiswa berperan sebagai penerima pesan, mendengarkan, memperhatikan, dan mencatat keterangan-keterangan yang disampaikan oleh dosen. Metode ini bukan merupakan cara terbaik untuk menyampaikan pesan karena working memory yang terbatas untuk memproses dan menyimpan informasi baru. Ketika kapasitas working memory sudah terlewati, maka kegiatan pembelajaran menjadi terganggu [3]. Oleh karena itu, mahasiswa tidak berperan aktif dalam proses pembelajaran TCL. Metode ini layak digunakan bila pesan yang disampaikan berupa informasi, jumlah mahasiswa terlalu banyak, dan dosen adalah seorang pembicara yang baik.

\section{Student centered}

learning

(SCL)merupakan salah satu pendekatan pengajaran dalam pendidikan. Pendekatan ini memberikan kebebasan kepada mahasiswa untuk memiliki kesempatan dan fasilitas menggali sendiri ilmu pengetahuannya sehingga akan didapat pengetahuan yang mendalam (deep learning) dan mampu meningkatkan kualitas mahasiswa. Perbedaan mendasar antara SCL dengan TCL terletak pada orientasinya. Strategi TCL lebih berorientasi pada konten (content oriented). Sedangkan strategi SCL lebih menekankan pada terjadinya kegiatan belajar oleh mahasiswa, atau berorientasi pada pembelajaran (learning oriented). Dosen pada SCL berperan sebagai fasilitator, motivator pembelajaran dan moderator proses diskusi. Dosen menyediakan beberapa media pembelajaran dan strategi belajar yang memungkinkan mahasiswa secara aktif memilih, menemukan dan menyusun pengetahuan serta cara mengembangkan keterampilan dan pengetahuannya.

Flipped classroom dapat diartikan sebagai model pembelajaran yang membalik pembelajaran tradisional, yaitu dengan membalik kegiatan ceramah dan tugas. Model pembelajaran flipped classroom dilakukan dengan cara mahasiswa melihat dan mendengarkan ceramah dosen melalui bantuan internet, misalnya dengan cara mengakses video dosen mengajar yang diunggah dalam sistem elearning. Kegiatan ini dilakukan sebelum mahasiswa masuk ke kelas. Kemudian setelah mahasiswa dan dosen bertemu di kelas, dosen akan memberikan aktivitas atau tugas di kelas. Aktivitas ini dapat berupa project based learning, problem based learning, presentasi, diskusi dan lain sebagainya. Semua aktivitas ini dapat meningkatkan pemahaman mahasiswa pada materi baru [4].

Mahasiswa yang belajar dengan menggunakan pendekatan flipped classroom akan dapat mempelajari video materi baru sesuai dengan kecepatan belajar setiap mahasiswa. Mahasiswa dapat menghentikan video untuk mencatat informasi baru dan memainkan ulang video untuk melakukan review materi yang masih belum dapat dipahami [2].

Oleh karena itu, pendekatan flipped classroom akan mendukung SCL. Mahasiswa diminta melakukan konstruksi pengetahuannya sendiri. Sedangkan dosen berperan sebagai fasilitator yang menyediakan media pembelajaran, moderator dan penasehat dalam proses diskusi, dan merancang strategi pembelajaran.

Media pembelajaran yang mendukung strategi flipped classroom adalah video. Penjelasan atau ceramah dosen didokumentasikan dalam bentuk video. Karakteristik video pembelajaran menurut menurut [5] meliputi kejelasan pesan yang akan disampaikan, stand alone, bahasa sederhana dan mudah dimengerti, materi representatif, visualisasi dengan media teks, animasi atau sound, mengggunakan kualitas grafis resolusi tinggi, dan dapat digunakan secara klasikal atau individual. 


\section{METODE}

Penelitian ini adalah merupakan jenis penelitian pengembangan (research and development). Prosedur pengembangan video pembelajaran dapat dilihat pada Gambar 1. Langkah-langkah pengembangan video pembelajaran menggunakan model 4D [7] yaitu 1) define (pendefinisian), 2) design (perancangan), 3) develop (pengembangan) dan 4) disseminate (penyebarluasan).

Kegiatan yang dilakukan dalam tahap define adalah identifikasi permasalahan yang terjadi, yang meliputi analisis kondisi saat ini, analisis kondisi ideal yang diinginkan, kesenjangan antara kondisi ideal dan kondisi saat ini, dan prioritas penyelesaian masalah. Analisis selanjutnya adalah front-end analysis yang meliputi analisis kebutuhan, analisis karakteristik mahasiswa, analisis tujuan, analisis materi dan analisis media.

Pada tahap design, materi pembelajaran akan disusun menjadi labsheet. Kemudian labsheetdidesain menjadi script video. Script video dinilai kelayakannya oleh ahli materi. Setelah script video dinilai layak, maka selanjutnya dilakukan persiapan shooting. Persiapan shooting meliputi pemilihan talent dosen, talent mahasiswa dan dubber. Talent dosen berperan sebagai presenter. Presenter akan memberi penjelasan pada bagian pembukaan dan penutupan. Presenter perlu menghafalkan scriptdan melatih ekspresi supaya terlihat alami di depan kamera. Talent mahasiswa berperan sebagai model yang melakukan semua kegiatan persiapan, eksperimen dan evaluasi. Dubber bertugas mengisi suara pada bagian persiapan, eksperimen dan evaluasi.

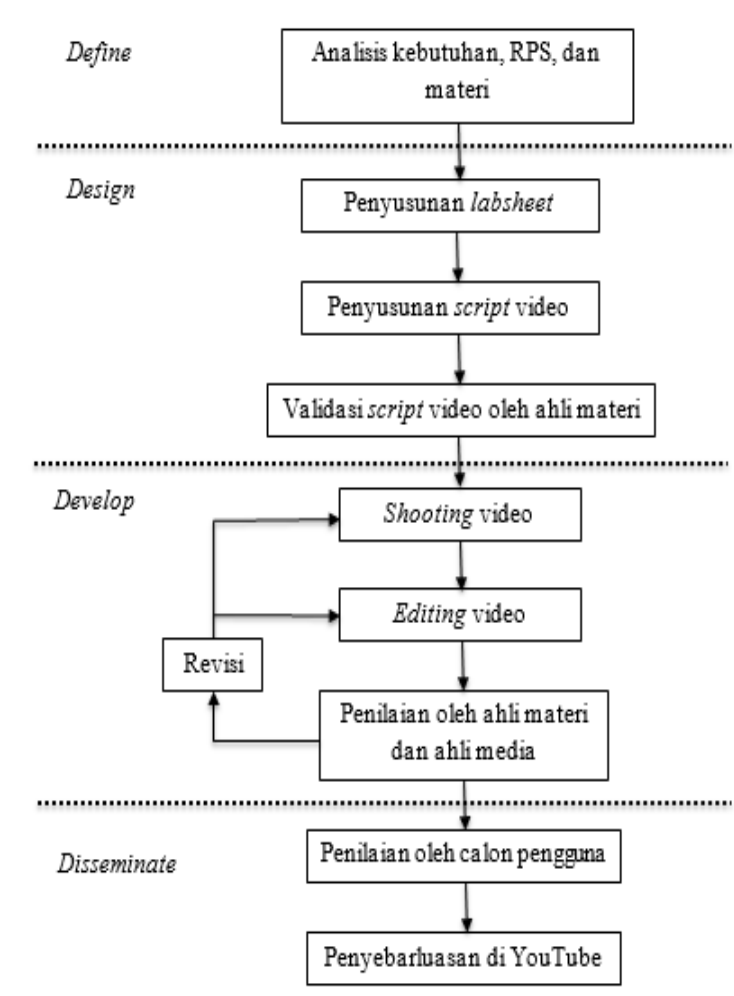

Gambar 1: Prosedur pengembangan penelitian

Pada tahap develop, script dikembangkan menjadi video pembelajaran. Pengembangan video pembelajaran dilakukan oleh LabTV Universitas Negeri Yogyakarta (UNY). Proses shooting indoor dilakukan di Laboratorium Kimia Fakultas Teknik, Universitas Negeri Yogyakarta. Shooting outdoor dilakukan di lingkungan Fakultas Teknik, Universitas Negeri Yogyakarta. Proses selanjutnya adalah editing video, yang dilakukan oleh editor dari LabTV Universitas Negeri Yogyakarta. Video pembelajaran yang sudah jadi kemudian dinilai kelayakannya oleh ahli materi dan ahli media. Video kemudian direvisi berdasar masukan dari ahli materi dan ahli media. Revisi dapat berupa shooting ulang untuk adegan tertentu atau proses editing ulang pada bagian tertentu.

Tahap terakhir yang dilakukan dalam penelitian ini adalah disseminate. Video disebarluaskan secara terbatas kepada calon pengguna, yaitu 30 mahasiswa program studi Pendidikan Teknik Boga, Fakultas Teknik, Universitas Negeri Yogyakarta. Calon pengguna diminta untuk menilai kelayakan video. Video yang dinyatakan layak sebagai 
media pembelajaran kemudian diunggah di YouTube channel Pendidikan Teknik Boga UNY supaya dapat digunakan oleh semua orang. Video kemudian disematkan pada elearning Pengujian Bahan Pangan.

Metode pengumpulan data dilakukan dengan angket uji kelayakan produk. Penilaian uji kelayakan menggunakan Likert skala 4. Data yang diperoleh kemudian dianalisis secara kuantitatif. Untuk menghitung persentase kelayakan dalam skala Likert digunakan rumus yang diadaptasi dari [6]:

$$
\text { Tingkat kelayakan }=\frac{\sum \text { total skor }}{\text { total skor ideal }} \times 100 \%
$$

Persentase skala Likert dikategorikan menjadi data kualitatif skala 4, yang dapat dilihat pada Tabel 1.

Tabel 1: Kategori skala persentase penilaian (Sugiyono, 2016:137).

\begin{tabular}{|l|l|}
\hline \multicolumn{1}{|c|}{ Persentase } & Kriteria \\
\hline \hline $75,1 \%-100 \%$ & Sangat layak \\
\hline $50,1 \%-75 \%$ & Layak \\
\hline $25,1 \%-50 \%$ & Kurang layak \\
\hline $0 \%-25 \%$ & Tidak layak \\
\hline
\end{tabular}

\section{HASIL DAN PEMBAHASAN}

Tahap define

Mata kuliah Pengujian Bahan Pangan merupakan mata kuliah wajib 3 SKS praktik di program studi Pendidikan Teknik Boga, yang ditempuh pada semester 4. Praktik kuliah Pengujian Bahan Pangan dilakukan dengan model pembelajaran kelompok. Mahasiswa dibagi dalam 8 kelompok. Anggota kelompok dipilih secara acak. Setiap kelompok terdiri dari 2-3 mahasiswa. Pada saat praktik, setiap kelompok mengerjakan eksperimen yang berbeda. Setelah praktik selesai, setiap kelompok akan mempresentasikan hasil kerjanya dan melakukan proses diskusi dengan kelompok lain. Dengan cara ini, kelompok yang tidak mengerjakan eksperimen tersebut menjadi memahami proses eksperimen kelompok lain. Berdasar hasil observasi dosen, mahasiswa kadang tidak memahami presentasi kelompok lain tentang suatu jenis eksperimen.

Media pembelajaran yang selama ini digunakan adalah handout, slide presentasi dan labsheet yang didistribusi kepada mahasiswa dengan menggunakan e-mail. Berdasar observasi tim dosen pengampu, mahasiswa sering tidak mempersiapkan diri sebelum mengikuti kegiatan praktik di Laboratorium Kimia, sehingga menyebabkan penurunan sikap kemandirian saat sedang praktik.

Selain itu, berdasar feedback dari mahasiswa, ada beberapa materi eksperimen dalam mata kuliah ini yang dirasa masih susah untuk dimengerti, sehingga memerlukan visualisasi lebih dalam. Salah stau materi yang dianggap memerlukan visualisasi mendalam adalah sifat fisik dan sifat emulsi telur.

Untuk meningkatkan keaktifan dan kemandirian mahasiswa saat praktik, pembelajaran mata kuliah Pengujian Bahan Pangan akan dilakukan dengan bantuan elearning dengan pendekatan flipped classroom. Pendekatan flipped classroom membutuhkan media pembelajaran yang berupa video tutorial. Video tutorial ini berisi penjelasan dosen dan hal-hal yang perlu diperhatikan saat praktik. Sampai dengan semester genap tahun ajaran 2016/2017, mata kuliah Pengujian Bahan Pangan belum memiliki video tutorial. Oleh karena itu, untuk mendukung pendekatan flipped classroom, akan dikembangkan video pembelajaran pada materi sifat fisik dan sifat emulsi telur.

\section{Tahap design}

Materi video pembelajaran Pengujian Bahan Pangan didesain sesuai dengan Rencana Pembelajaran Semester (RPS) Pengujian Bahan Pangan. Sebelum dibuat dalam video pembelajaran, materi disusun dalam bentuk labsheet. Labsheet kemudian disusun menjadi script video. Script video dinilai kelayakannya oleh ahli materi. Script video dinilai layak sehingga dapat digunakan untuk shooting. 


\section{Tahap develop}

Video dibagi menjadi 5 bagian yaitu pembukaan, persiapan alat dan bahan, proses eksperimen, evaluasi hasil dan penutupan. Bagian pembukaan dan penutupan disampaikan oleh presenter. Pengambilan gambar pada scene presenter dilakukan mulai dari bagian kepala sampai dengan pinggang, untuk memastikan mahasiswa fokus kepada presenter. Kecepatan suara diatur supaya tidak terlalu cepat, supaya mahasiswa memahami materi yang disampaikan. Kemudian ekspresi wajah juga harus natural, mata fokus ke kamera dan bibir tersenyum. Senyum akan memberi kesan ramah, yang secara tidak langsung merupakan interaksi antara presenter dengan mahasiswa yang menyaksikan video ini.

\section{Pembukaan}

Gambar 2 menunjukkan bagian pembukaan. Presenter mengawali video dengan cara memberi sapaan kepada mahasiswa dan menjelaskan capaian pembelajaran. Kemudian presenter menjelaskan secara sekilas dasar teori sifat fisik dan sifat telur.

Untuk mempermudah pemahaman mahasiswa, penjelasan presenter juga dilengkapi dengan teks, gambar atau animasi. Ketika presenter mengucapkan suatu materi, maka teks yang berisi keyword materi tersebut akan masuk ke dalam scene, seperti yang dapat dilihat pada Gambar 3. Gambar juga dapat masuk ke dalam scene saat presenter sedang menyampaikan materi tersebut (Gambar 4). Scene presenter dilengkapi dengan teks, gambar atau animasi supaya mahasiswa tidak bosan saat melihat video tersebut.

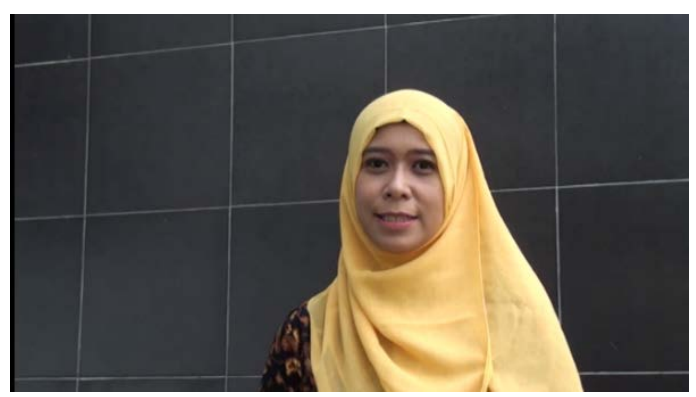

Gambar 2: Pembukaan oleh presenter

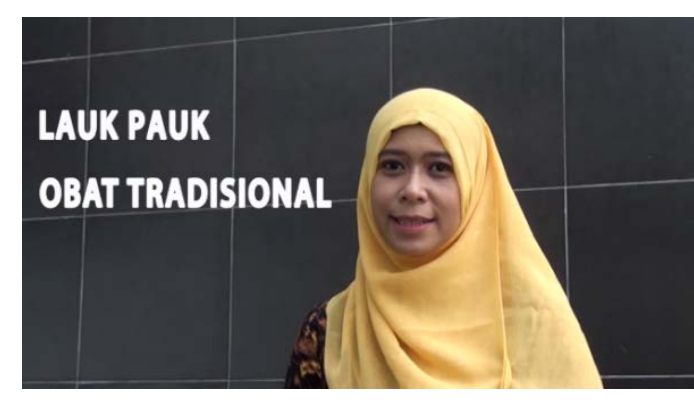

Gambar 3: Scene presenter dengan variasi teks

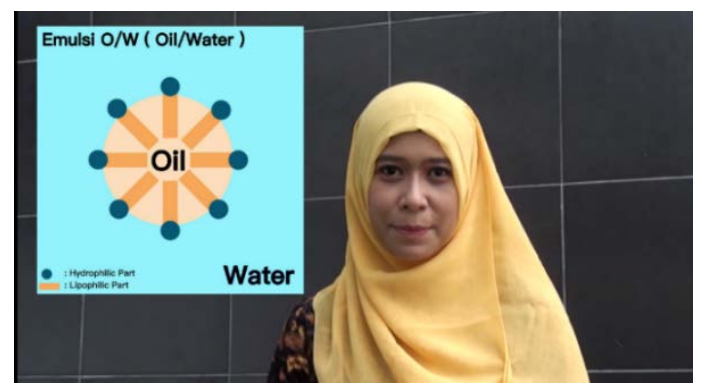

Gambar 4: Scene presenter dengan variasi gambar

\section{Persiapan alat dan bahan}

Gambar 5 dan 6 adalah bagian persiapan alat dan bahan. Bagian persiapan alat dan bahan dipandu oleh dubber yang menyebutkan nama alat dan bahan yang digunakan pada eksperimen ini, dan talent mahasiswa yang menunjukkan alat dan bahan tersebut.

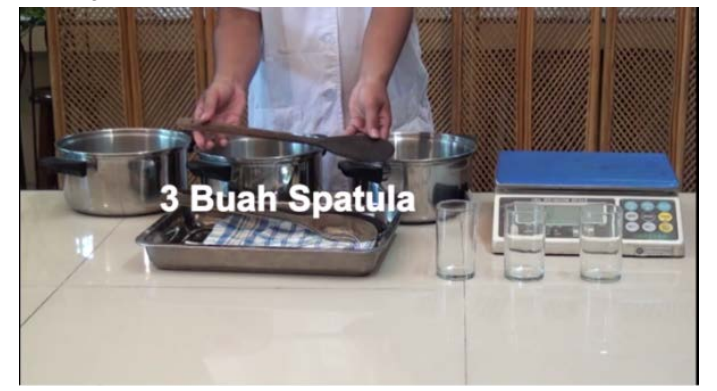

Gambar 5: Persiapan alat

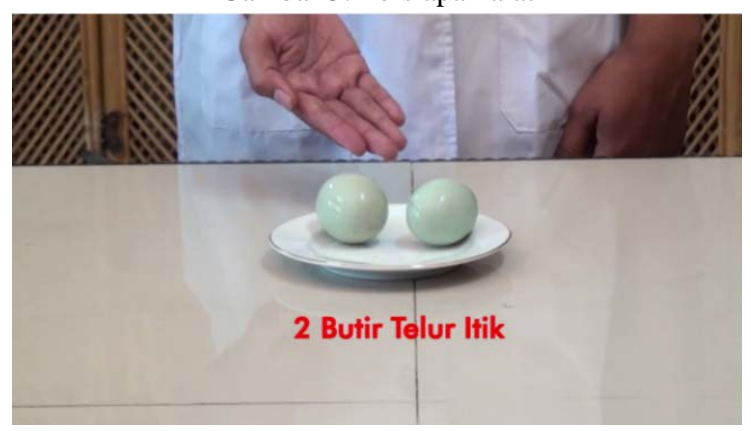

Gambar 6: Persiapan bahan

Bagian persiapan alat dan bahan diakhiri dengan daftar alat atau bahan yang digunakan 
dalam eksperimen ini, seperti yang terdapat pada Gambar 7.

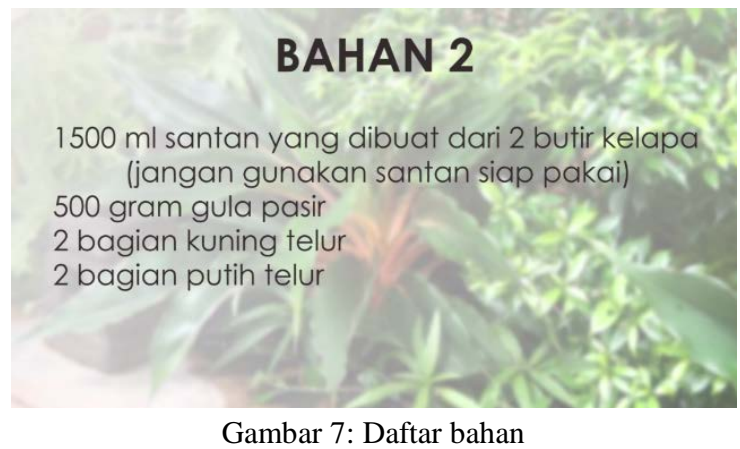

Proses eksperimen

Proses eksperimen dapat dilihat pada Gambar 8. Dubber menjelaskan proses eksperimen yang harus dilakukan dan talent mahasiswa memeragakan kegiatan eksperimen tersebut. Apabila terdapat proses eksperimen yang kritis atau memiliki tingkat kesulitan tinggi, maka gambar akan diperbesar (zoom) dan penjelasan tentang eksperimen yang kritis tersebut dilakukan oleh dubber (Gambar 9). Penjelasan eksperimen yang kritis juga dapat disampaikan oleh presenter.

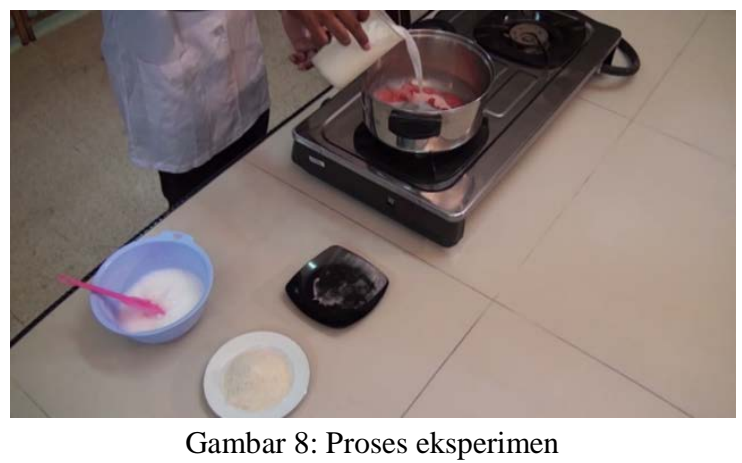

Bagian eksperimen juga dilengkapi dengan gambar yang berupa tabel yang harus dilengkapi oleh mahasiswa saat proses eksperimen, seperti yang dapat dilihat pada Gambar 10. Bagian yang diberi warna hijau adalah bagian tabel yang harus diisi dalam proses eksperimen tersebut.

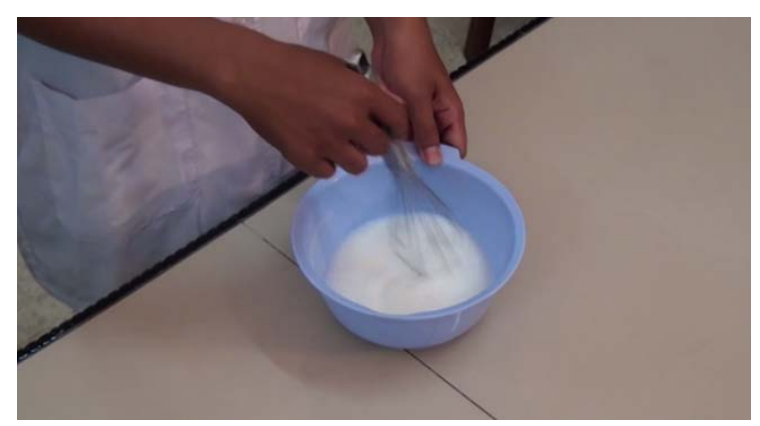

Gambar 9: Zoom gambar pada proses kritis

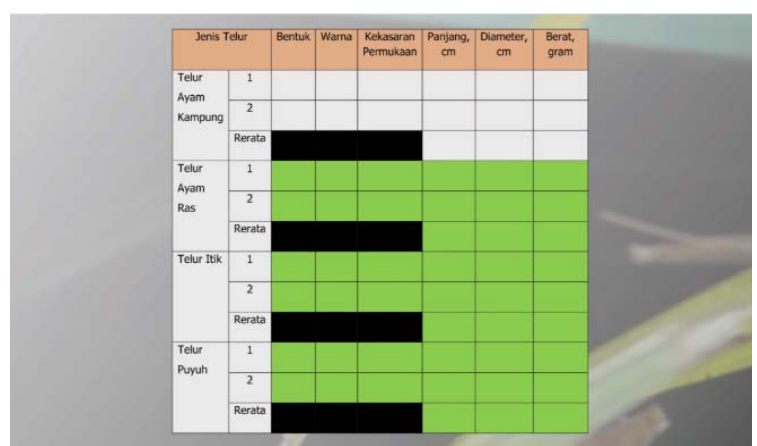

Gambar 10: Tabel hasil pengamatan eksperimen

Evaluasi hasil

Evaluasi hasil dilakukan dengan cara peragaan hasil eksperimen oleh talent mahasiswa dengan bantuan suara dubber sebagai narasi (Gambar 11). Bagian evaluasi ini juga dapat dilengkapi dengan teks, gambar atau animasi untuk mempermudah visualisasi.

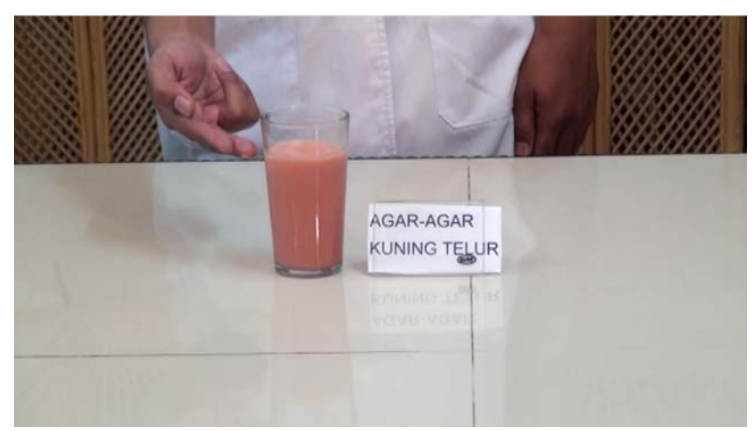

Gambar 11: Evaluasi hasil oleh talent mahasiswa dan dubber

Evaluasi yang memerlukan bantuan gambar atau animasi akan dilakukan oleh presenter, seperti yang dapat dilihat pada Gambar 12 dan 13. Gambar 12 menunjukkan evaluasi dengan bantuan gambar. Evaluasi juga dapat dilengkapi dengan animasi yang tersedia bebas di internet, seperti pada Gambar 13. 
Animasi digunakan untuk mempermudah visualisasi mahasiswa terhadap proses-proses yang abstrak. Animasi yang digunakan pada video pembelajaran ini menjelaskan tentang cara kerja emulsifier dalam campuran air dan minyak.

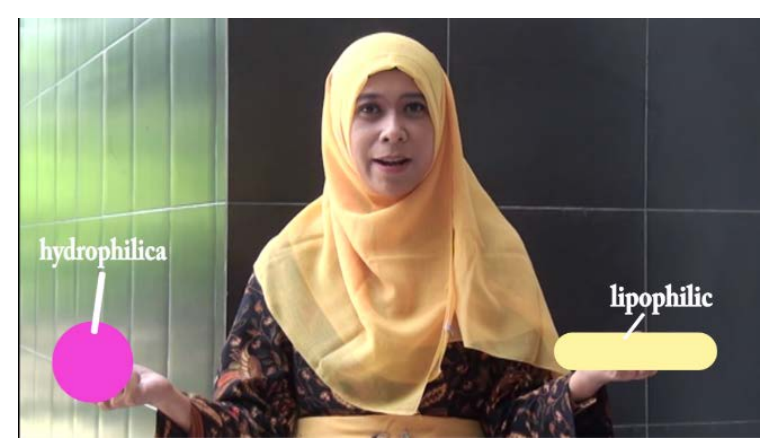

Gambar 12: Evaluasi hasil oleh presenter dengan bantuan gambar

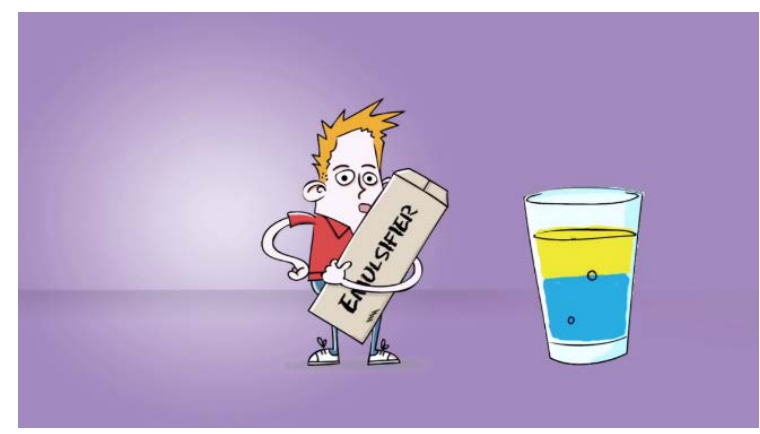

Gambar 13: Evaluasi hasil oleh presenter dengan bantuan animasi

\section{Penutupan}

Gambar 14 menunjukkan bagian penutupan yang disampaikan oleh presenter dengan sapaan yang memberi semangat kepada mahasiswa supaya dapat melakukan eksperimen tersebut dengan lancar.

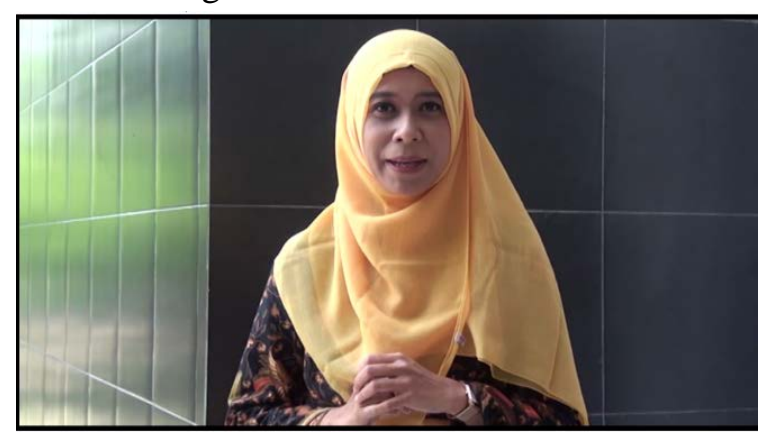

Gambar 14: Penutupan oleh presenter

Penilaian ahli materi dan ahli media
Video yang sudah selesai proses editing, kemudian diuji kelayakannya oleh ahli materi dan ahli media. Revisi video dilakukan sesuai saran ahli materi dan ahli media. Ahli materi menilai kelayakan video dari aspek pembelajaran, materi, manfaat dan kemudahan penggunaan. Sedangkan ahli media menilai kelayakan video dari aspek media, kecocokan video sebagai media pembelajaran SCL, manfaat dan kemudahan penggunaan. Penilaian dari ahli materi dan ahli media dapat dilihat pada Tabel 2 dan 3.

Tabel 2: Kelayakan video pembelajaran berdasar ahli materi

\begin{tabular}{|l|r|l|}
\hline Aspek & $\begin{array}{c}\text { Prosentase } \\
\text { Kelayakan }\end{array}$ & Kategori \\
\hline \hline Pembelajaran & $93 \%$ & Sangat Layak \\
\hline Materi & $95 \%$ & Sangat Layak \\
\hline Manfaat & $100 \%$ & Sangat Layak \\
\hline Penggunaan & $100 \%$ & Sangat Layak \\
\hline Total & $96 \%$ & Sangat Layak \\
\hline
\end{tabular}

Tabel 3: Kelayakan video pembelajaran berdasar ahli media

\begin{tabular}{|l|r|l|}
\hline Aspek & $\begin{array}{c}\text { Prosentase } \\
\text { Kelayakan }\end{array}$ & Kategori \\
\hline \hline Media & $87 \%$ & Sangat Layak \\
\hline Media SCL & $95 \%$ & Sangat Layak \\
\hline Manfaat & $85 \%$ & Sangat Layak \\
\hline Penggunaan & $92 \%$ & Sangat Layak \\
\hline Total & $88 \%$ & Sangat Layak \\
\hline
\end{tabular}

Berdasar penilaian ahli materi dan ahli media, video pembelajaran ini dinyatakan memiliki kualitas materi dan media yang sangat layak. Video pembelajaran ini juga dinilai sangat layak dari aspek kemanfaatan dan kemudahan penggunaan. Oleh karena itu, video pembelajaran ini dinyatakan sangat layak untuk digunakan sebagai media pembelajaran.

\section{Tahap disseminate}

Video ini kemudian diuji kelayakannya oleh calon pengguna yaitu 30 mahasiswa program studi Pendidikan Teknik Boga. Uji kelayakan calon pengguna menunjukkan prosentase kelayakan $81 \%$ sehingga dinyatakan sangat layak digunakan sebagai media pembelajaran.

Video kemudian diunggah di YouTube channel Pendidikan Teknik Boga Universitas 
Yogyakarta dengan URL https://youtu.be/10b_F_2pAQU dan disematkan dalam course e-learning Pengujian Bahan Pangan. Video pembelajaran ini dapat digunakan oleh mahasiswa Universitas Negeri Yogyakarta maupun oleh masyarakat yang melakukan searching di YouTube.

\section{SIMPULAN}

Video pembelajaran pada mata kuliah Pengujian Bahan Pangan untuk materi sifat telur telah dikembangkan dengan pendekatan 4D (define, design, develop dan disseminate). Video ini menjelaskan sifat fisik dan sifat emulsi telur. Video menggunakan format mp4, dengan durasi 11 menit dan diunggah di YouTube Channel Pendidikan Teknik Boga UNY dengan URL https://youtu.be/ 10b_F_2pAQU. Video materi telur mendapat penilaian kelayakan oleh ahli materi $96 \%$ dalam kategori sangat layak, ahli media 88\% sangat layak dan calon pengguna $83 \%$ sangat layak, sehingga video ini dinyatakan sangat layak untuk digunakan sebagai media pembelajaran.

\section{REFERENSI}

[1] Bergmann, J. and Sams, A. (2012) Flip your classroom: Reach every student in every class every day. Eugene, Oregon:International Society for Technology in Education.

[2] Educause (2012) 7 things you should know about... Flipped classrooms. Educause Learning Initiative. https://net. educause.edu/ir/library/pdf/ELI7081.pdf.

[3] Hamdan, M., McKnight, P., McKnight, K., and Arfstrom, K. (2013) A review of flipped learning: $\quad$ Flipped Learning Network.http://researchnetwork.pearson.co $m / w p$-content /uploads/LitReview_FlippedLearning1.pdf.

[4] Mazur, A.D., Brown, B., and Jacobsen, M. (2015) Learning designs using flipped classroom instruction, Canadian Journal of Learning and Technology, 41(2), 1-26.

[5] Riyana, C. (2007) Pedoman Pengembangan Media Video. Jakarta: P3AI. UPI.

[6] Sugiyono (2016) Metode Penelitian Pendidikan Pendekatan Kuantitatif, Kualitatif, dan R\& D. Bandung: Alfabeta.

[7] Thiagarajan, S., Semmel, D.S., and Semmel, M.I. (1974) Instructional Development for Training Teachers of Exceptional Children, University of Minnesota. 